\title{
How Far Can Citizens Influence the Decision-Making Process? Analysis of the Effectiveness of Referenda in the Czech Republic, Slovakia and Hungary in 1989-2015
}

\author{
Elżbieta Kużelewska \\ Centre for Direct Democracy Studies, \\ Department of Political Science, \\ Faculty of Law, \\ University of Białystok \\ ul. Mickiewicza 1, \\ Białystok 15-213, Poland \\ E-mail: ekuzelewska@gmail.com
}

\begin{abstract}
This article explores the political role of a referendum in Central European countries, in particular in Hungary, Slovakia, and the Czech Republic. In this article, political effectiveness is understood as a possibility to influence the decision-making process by citizens through a referendum. The transformation of political systems in Central European states from socialist/communist to democratic ones resulted in increasing interest in the notion of referendum, one of the common forms of direct democracy. However, most referenda have been abused for political purposes. The focus of this article is a referendum used at the national level. This study examines the use of a referendum in Central European states from 1989 to 2015. The database presents, country by country, the subject matter of voting, people's participation and the results in order to show the citizens' opportunity (or lack of it) to express their opinions and to contribute to policy-making by circumventing the standard legislative process. The aim of this paper is to analyze referenda in the selected countries and to verify two hypotheses. Firstly, the weak use of a referendum and a small size of complementation of representative democracy. Secondly, the citizens' belief in a referendum as an element of communication and consultation between authorities and society.
\end{abstract}

Keywords: Czech Republic, direct democracy, Hungary, participation, referendum, Slovakia

1 This article is based on research carried out under project no. 2014/15/B/HS5/01866 of the National Science Centre, Poland. 


\section{Introduction}

There are many reasons for examining the notion of a referendum at the national level in small countries of Central Europe - the Czech Republic, Slovakia, and Hungary (Poland is not included in the analysis). The level of civic participation in decision-making is an important element of discussions on the condition of contemporary democracy. The opportunity to participate in what is broadly understood as political life, and people's influence on the authorities are among the fundamental principles of democracy. The real and effective participation of citizens in the decision-making process is recognized as a phenomenon crucial to the development of a strong and stable democracy. Apart from elections, a referendum is one of the key procedures to enable citizens to influence the political life. The 'size' of Central European states (and the number of their population) fits Dahl's view that the smaller a democratic body, the greater the possibility of citizens' participation, and the smaller the need to give a decisionmaking power to the representatives (Dahl, 2000, p. 104).

After the collapse of the communist regime in Europe in 1989 and, finally, the collapse of the Soviet Union in 1991, the European states that were previously kept under Soviet influence started to create a new political system with an emphasis on direct democratic institutions, especially a referendum. They have forgotten the communist heritage and have transformed their political regime from communist to democratic. The countries under discussion form the Visegrad Group, ${ }^{2}$ and are members of NATO and the EU. All of them introduced direct democratic procedures supporting representative democracy and referenda were put to the test.

The interest in direct democracy as people's activism in Central Europe has grown considerably after the collapse of the communist regime. However, people's participation has come into vogue in Western democracies already earlier (Lucas, 1976, p. 136). It seems that direct democracy, in particular referendum and citizens' initiative, is becoming more significant in political life in Central Europe. It is reflected in the fact that a growing number of issues has been attempted to be solved through a referendum. In total, from

2 The Visegrad Group (Visegrad Four or V4) was formed in February 1991 in Visegrad, Hungary, at a meeting of the President of the Czechoslovak Republic, Václav Havel, the President of Poland, Lech Wałęsa and the Prime Minister of Hungary, József Antall. Visegrad Four reflects the efforts of the countries of Central European region to work together in fields of common interest within the all-European integration. 
November 1989 to February 201515 referenda were conducted in Czech Republic, Slovakia and Hungary (and the voters had to answer a total number of 31 questions). In Czechoslovakia, there was no referendum on the breakup because it was opposed by the leading parties, which had the legislative power to block it, despite demands by the opposition parties (Bookman, 1994, p. 176). In the 1990s, many political and economic reforms have been also implemented with the help of a referendum. This shows that a referendum seems to play an important role in the development of new political systems in Central Europe and the people's participation in the political life of these countries is worth examining.

The empirical part of this paper is based on statistical data (on the quantity, time, subject and referenda results), which are useful in analyzing an application of nationwide referenda within the states concerned in this paper.

The aim of this paper is to analyze the effectiveness of referenda (understood as a possibility to influence decision-making process by the citizens) in selected countries and verify two hypotheses:

Firstly, (1) there are some important similarities in the socio-political perception of referendum in Central European states. These similarities concern the weak usage of referendum. (2) It is difficult to notice citizens' pressure on a wider scale using referendum as an element of communication and consultation between authorities and society. There is one important aspect - people's belief in political influence. Do citizens really believe in their ability to influence what the government does?

Secondly, referendum is poorly aimed at complementing representative democracy in Central Europe. Policy-makers usually organize it in order to achieve their own political interests at the expense of the opposition. Referendum is used as a tool to suit the needs of the government rather than the interests of democracy.

The political role and effectiveness of a referendum will be measured in this article by the number of conducted referenda, their validity, people's participation and the results.

This article is divided into four parts. Section 1 starts with a general analysis of the constitutional background of referendum and its procedures as well as a comparison of regulations in the respective countries. Section 2 describes the referendum experience, subjects of vote, initiators of the vote, and referenda results. Referenda on the EU membership are discussed in Section 3. Finally, 
Section 4 will draw some conclusions from comparing referendum experience in Central European states and look at impacts of political pressure on the results and turnout in referendum.

\section{Constitutional baseis of referenda in the Czech Republic, Slovakia, and Hungary}

A referendum is defined in this article as a publicly recognized institution where citizens decide their opinion on issues - other than through legislative or executive elections-directly at the ballot box through universal and secret suffrage (Altman, 2014, p. 7). The Constitutions of Central European countries examined here provide that the country is democratic and a nation is a sovereign. Democracy is defined as a government in which the will of the majority of qualified citizens rules (Dahl, 2000, pp. 80-82). In Schumpeter's (1950, p. 269) view, it is rather a political method, a certain institutional arrangement for arriving political, legislative and administrative decisions in which voters acquire the power to decide by means of a competitive struggle for the people's vote. Dahl's (1971, p. 3) definition of polyarchy focuses on the leaders' elections through free and fair elections in which most of the adult population have the right to vote and run for public office.

The beginnings of the theory of sovereignty are found in Aristotle's Politics. There is a recognition of the fact that there is a supreme power in the state, and this power may be in the hands of one, of a few, or of many. The general concept of internal sovereignty is divided into political and legislative sovereignty (Suksi, 1993, pp. 16-17). Rousseau (2003[1762], pp. 28-33) has viewed the people as possessing both political and legislative sovereignty, while Bentham (2001[1891], p. 137) and Locke (1689) have limited the role of the people to political sovereignty and tended to leave the legislative power in the hands of a distinct body elected or designated by the people.

The sovereignty exercises its authority either directly or indirectly and de facto. The former is an exception to the latter. ${ }^{3}$ It should be stressed that only Hungary

3 Article 2, Paragraph 1 of the Constitution of Czech Republic (1992) states that the people are the source of public power. Article 2, Paragraph 1 of the Constitution of Slovakia (1992) provides that the state power comes from people who do it through their elected representatives or directly. Article B(3)(4) of the Fundamental Law of Hungary (2011) declares that the source of public power shall be the people. The people shall exercise its power through its elected representatives, or, in exceptional cases, in a direct manner. 
has not enacted a new constitution after the collapse of the communism. The Hungarian constitution of 1949 was enforced until 2011, however in 1989 it was amended (Brodziński, 2012, pp. 1-2). In 1989 the Parliament amended the Constitution and adopted the first Act on Referendum (Act No. XVII). The Regulation of 1989 considered the national referendum as a way of exercising powers. In 1998, the Constitution was amended again and the Parliament adopted a new Act on National Referendum. These documents focused on the initiation procedure, the possibilities of raison a question to a referendum, etc. (Csink, 2013, p. 61).

All of these constitutions provide for a referendum, however, a referendum is quite a new institution in Central European countries' public law. Nevertheless, there are some crucial differences. First, the Constitution of the Czech Republic (1992) laconically regulates the legal basis to refer to a referendum. Generally it supports the principle of representative democracy. Article 2 creates the possibility of recourse to a referendum, setting up a legal basis given to the legislative branch-"constitutional act may define when the people exercise state power directly". The word "when" means that the people are allowed to directly rule by a constitutional act that is passed each time, not as a sound legal basis (Skotnicki, 2000, p. 17). The other analyzed constitutions include a separate article concerning a referendum.

Secondly, the constitutions of Hungary and Slovakia mention the issues excluded from national referendum. Thirdly, the Constitution of Slovakia (Art. 98) describes situations when a referendum is binding while the constitution of Hungary in Article 8, Paragraph 4 underlines both the binding of a referendum and its validity.

\subsection{Hungary}

According to Article 8 of the Fundamental Law (2011), Parliament shall order a referendum upon the motion of at least 200,000 voters. Parliament may also order a national referendum upon the motion of the President of the Republic, the government, or one 100,000 electors. The decision made by any valid and conclusive referendum shall be binding in Parliament.

National referenda may be held on any matter within Parliament's responsibilities and competences. There are some issues excluded from national referendum such as budget, central government taxes, duties, the central regulation of local taxes, international treaties, the declaration of war, states of emergency, and other issues (Fundamental Law, 2011, Art. 8, Para. 3). 
A national referendum is valid if more than half of all electors have cast a valid vote, and shall be conclusive if more than half of all voters casting a valid vote have given the same answer to a question. What are the consequences of this regulation? The opponents of the proposal might be interested in boycotting the referendum instead of forcing their supporters to vote against the proposal. In turn, the supporters of the proposal can only be sure in their success if more than half of all participants vote in favour of the referendum.

\subsection{Slovakia}

According to Article 95 of the Constitution of the Slovak Republic (1992), it is possible to hold a referendum on the basis of resolution of the National Council as well as by the popular initiative supported by 350,000 citizens entitled to vote. A referendum is organized by the President and it cannot take place during the 90 days preceding parliamentary elections. A referendum may be held on the day of parliamentary elections (Constitution of the Slovak Republic, 1992, Art. 97). This solution raises the question of the need of a popular vote. If a referendum and the parliamentary elections are on the same day, it makes no sense and undermines the significance of the parliament. A referendum is binding if the vote was attended by more than half of eligible citizens and more than half of the participating are in favor of it (Constitution of the Slovak Republic, 1992, Art 98). Article 98 declares that referendum on the same subject may be held after at least three years. The Constitution guarantees the stability of the referendum decision: the Parliament can amend or repeal the result of referendum by constitutional statue after three years of its legitimization.

According to Articles 7, Paragraph 1, and 93, the referendum approves the constitutional act of entry (or occurrence) to the Union states. Due to Article 93, other momentum issues of public interest could be decided in a referendum. At the same time Article 93, Paragraph 3 indicates that the subject of vote in referendum could not refer to fundamental rights and freedoms, taxes, conscription and the state budget. In accordance with Article 30 of the Constitution the citizens have the right to participate in the administration of public affairs either directly or through the free election of their representatives. It means that the Slovaks have the right of direct deciding about the civil rights (Zieliński, 2003, p. 60). 
Table 1. Compulsory and non-compulsory (optional) referenda in Central Europe

\begin{tabular}{|c|c|c|c|}
\hline Country & Hungary & Slovakia & $\begin{array}{l}\text { The Czech } \\
\text { Republic }\end{array}$ \\
\hline $\begin{array}{l}\text { Compulsory } \\
\text { referendum }\end{array}$ & $\begin{array}{l}\text { The EU membership } \\
\text { (Art. 79) }\end{array}$ & $\begin{array}{l}\text { Constitutional } \\
\text { referendum } \\
\text { Art. 93, Para. } 1 \\
\text { referendum on } \\
\text { entry or leaving the } \\
\text { international union }\end{array}$ & No \\
\hline $\begin{array}{l}\text { Non- } \\
\text { compulsory } \\
\text { referendum }\end{array}$ & $\begin{array}{l}\text { Constitutional } \\
\text { referendum } \\
\text { (Art. 28B) held } \\
\text { on the general } \\
\text { principles } \\
\text { Legislative } \\
\text { referendum } \\
\text { (Art. 28B) } \\
\text { Issue referendum } \\
\text { (Art. 28B) on the } \\
\text { matters of cognition } \\
\text { of National Assembly } \\
\text { except from } \\
\text { limitations mentioned } \\
\text { by the Constitution } \\
\text { Consultative } \\
\text { referendum } \\
\text { (Art. 28C) }\end{array}$ & $\begin{array}{l}\text { Issue referendum } \\
\text { Art. 93, Para. } 2 \\
\text { concerning the } \\
\text { solemn matters of } \\
\text { public life, except } \\
\text { from limitations } \\
\text { mentioned in the } \\
\text { Constitution } \\
\text { Arbitrage referendum } \\
\text { (Art. 101)-it is } \\
\text { initiated by the } \\
\text { Parliament and } \\
\text { its subject can be } \\
\text { impeachment of } \\
\text { the President; if } \\
\text { the result of the } \\
\text { vote is positive } \\
\text { for the President } \\
\text { the Parliament is } \\
\text { dissolved }\end{array}$ & $\begin{array}{l}\text { Accession } \\
\text { referendum } \\
\text { (Art. 10a) }\end{array}$ \\
\hline
\end{tabular}

Source: Rytel-Warzocha, 2011, pp. 131-132

\subsection{Czech Republic}

As mentioned above, the Constitution of the Czech Republic (1992) supports the principle of representative democracy. However, Article 2 of the Constitution creates the possibility of recourse to a referendum, setting up a legal basis given to the legislative branch. This is due to the constitutional amendment "integration clause" that was introduced (Constitution of the Czech Republic, 1992, Art. 10a). In the added Article 10a, a possibility to pass over certain competences of state authority to the international organizations or institutions was allowed. Yet, Article 10a, Paragraph 2 provides that this agreement could be completed only 
after parliamentary consent for its ratification unless due to constitutional act in the particular case that parliamentary procedure is replaced by the obligation to hold a referendum. According to the Constitutional Amendment (2003), the Constitution was supplemented by rules given by the presidential authority to call the referendum and announce its result. These regulations were reduced exclusively to the referendum on the EU membership. The Czech political elites support the traditional way of solving public affairs (in cabinets) and do not prefer consulting public opinion in a referendum (Zieliński, 2003, p. 55).

\section{Table 2. Referendum framework in Central Europe}

\begin{tabular}{|c|c|c|c|}
\hline $\begin{array}{l}\text { Referen- } \\
\text { dum }\end{array}$ & Hungary & Slovakia & The Czech Republic \\
\hline Initiative & $\begin{array}{l}\text { Parliament upon the } \\
\text { motion of President, } \\
\text { Government or } \\
100,000 \text { electors; } \\
\text { Referendum shall } \\
\text { be ordered upon the } \\
\text { motion of at least } \\
200,000 \text { electors }\end{array}$ & $\begin{array}{l}\text { President upon the } \\
\text { motion of at least } \\
350,000 \text { electors, } \\
\text { or on the basis of } \\
\text { resolution of the } \\
\text { National Council }\end{array}$ & The President \\
\hline Validity & $\begin{array}{l}\text { Referendum shall be } \\
\text { valid if more than half } \\
\text { of all electors have } \\
\text { cast a valid vote; } \\
\text { Referendum shall be } \\
\text { conclusive if more } \\
\text { than half of all voters } \\
\text { casting a valid vote } \\
\text { have given the same } \\
\text { answer to a question }\end{array}$ & $\begin{array}{l}\text { Results of referendum } \\
\text { are binding if more } \\
\text { than half of all } \\
\text { electors have voted } \\
\text { and the decision } \\
\text { was accepted by } \\
\text { more than half of all } \\
\text { voters participating in } \\
\text { referendum }\end{array}$ & $\begin{array}{l}\text { Regardless of the } \\
\text { turnout the outcomes } \\
\text { are binding; }\end{array}$ \\
\hline $\begin{array}{l}\text { Excep- } \\
\text { tions }\end{array}$ & $\begin{array}{l}\text { Art. } 8 \text {, Para. } 3 \text { of the } \\
\text { Constitution }\end{array}$ & $\begin{array}{l}\text { 1. Art. 93, Para. } 3 \text { of } \\
\text { the Constitution } \\
\text { 2. Referendum on the } \\
\text { same subject may } \\
\text { be held after at least } \\
\text { three years }\end{array}$ & $\begin{array}{l}\text { In the case of } \\
\text { rejection of the } \\
\text { EU membership, } \\
\text { referendum on the } \\
\text { same issue can be } \\
\text { held in two years }\end{array}$ \\
\hline
\end{tabular}

Source: Author's compilation

The constitutions of the three countries recognize the institution of a referendum. However, there are some differences. The Czech constitution does 
not introduce a mandatory referendum, while the Slovak and Hungarian provide for an obligatory referendum on the entry to the international union (or leaving, according to the Slovak constitution).

In the Czech Republic, the President initiates the referendum. In Slovakia and Hungary, both the Parliament and the citizens can initiate the referendum. The similarities are also seen in (1) the validity of a referendum (depending on the turnout; in all examined countries referenda have to meet certain turnout requirements in order to be valid); (2) exceptions - the situation when a referendum cannot be held again (on the same subject matter it can be conducted after three years in Slovakia and two years in the Czech Republic).

\section{The referenda "deepening" political transformation in Central Europe}

A specific category of referenda that have been held in Central Europe after 1989 can be described as "deepening" referenda. This term was created to underline the role of this institution of direct democracy in reforming political and economic process of so-called "young democracies". The citizens of Hungary and Slovakia themselves directly decided on electoral systems for the parliamentary and/or presidential elections, and an adoption of reforms in privatization or insurance system. The Czechs have not voted, not even once. As Valach writes, the Czech citizens have experienced only 30 years of democracy during the past 100 years and they are suffering from a lack of trust in their own ability (Valach, 2004, p. 48) to directly express their opinions.

The use of referendum has been of exceptional character so far, as only five "reforming referenda" in Hungary and seven in Slovakia have been held since the democratic transition in 1989.

The voters had to answer a total number of 28 questions regarding political and economic transformation. Low turnout resulted in the invalidity of all Slovakian and two Hungarian referenda. The significantly low turnout of the "deepening" referenda (especially in Slovakia) resulted from a few factors. Firstly, some of these questions were too difficult to answer for a regular person and there have been a specific kind of "renationalization" of society. An ordinary citizen was unable to make informed decisions about an extremely complex problem. A referendum was not seen by the electors as an element of communication and consultation between authorities and society. The voters realized that the policy-makers in Central Europe usually 
organized a referendum to achieve their own political interests at the expense of the opposition. Secondly, all Slovakian referenda were held in an atmosphere of disputes between the governmental coalition or between the government and the opposition political parties (Haughton, 2002, p. 1331; 2003, p. 276; Pridham, 2002, pp. 212-213; Kużelewska, 2014, p. 105; Podolak, 2014, p. 352). The most crucial referendum concerned accession to the NATO. The institution of a referendum was discredited as a result of the current aspirations of the Prime Minister Mečiar (Glajcar, 2004, p. 309). The Constitutional Court of Slovakia confirmed that the government unconstitutionally intervened in organizing the referendum and ordered the Minister of Interior (who was technically responsible for it) to withdraw from the ballot paper the question proposed by the opposition parties and concerning direct presidential elections (Kusý, 1999, p. 108).

Table 3. Referenda deepening political transformation in Hungary, Slovakia and the Czech Republic

\begin{tabular}{|c|c|c|c|c|c|}
\hline Country & $\begin{array}{l}\text { Date of } \\
\text { vote }\end{array}$ & Subject of referendum & $\begin{array}{l}\text { Turnout, } \\
\%\end{array}$ & $\begin{array}{l}\text { In fa- } \\
\text { vour, \% }\end{array}$ & $\begin{array}{l}\text { Re- } \\
\text { sult }\end{array}$ \\
\hline \multirow[t]{11}{*}{ Hungary } & \multirow{4}{*}{$\begin{array}{l}26 \text { No- } \\
\text { vember } \\
1989\end{array}$} & $\begin{array}{c}\text { Election of the President by } \\
\text { Parliament }\end{array}$ & 58.04 & 50.07 & Yes \\
\hline & & $\begin{array}{l}\text { Dissolution of Betrieb- } \\
\text { skampftruppen (Worker's } \\
\text { Guard) }\end{array}$ & 58.04 & 94.94 & Yes \\
\hline & & $\begin{array}{l}\text { Disclosing the accounts and } \\
\text { property of the USAP }\end{array}$ & 57.85 & 95.37 & Yes \\
\hline & & $\begin{array}{l}\text { Ending the presence of political } \\
\text { parties in business }\end{array}$ & 58.04 & 95.15 & Yes \\
\hline & $\begin{array}{l}29 \text { July } \\
1990\end{array}$ & Direct election of the President & 13.91 & 85.90 & No \\
\hline & $\begin{array}{l}16 \text { No- } \\
\text { vember } \\
1997\end{array}$ & Accession to the NATO & 49.19 & 85.33 & Yes \\
\hline & \multirow{2}{*}{$\begin{array}{l}5 \text { De- } \\
\text { cember } \\
2004\end{array}$} & $\begin{array}{l}\text { Privatization within the health } \\
\text { care system }\end{array}$ & 37.41 & 65.01 & No \\
\hline & & Double citizenship & 37.41 & 51.57 & No \\
\hline & \multirow[t]{3}{*}{$\begin{array}{l}9 \text { March } \\
2008\end{array}$} & $\begin{array}{l}\text { Abolition of fees for in-patient } \\
\text { treatments }\end{array}$ & 50.49 & 84.08 & Yes \\
\hline & & $\begin{array}{l}\text { Abolition of tuition fees for } \\
\text { higher public education }\end{array}$ & 50.49 & 82.22 & Yes \\
\hline & & $\begin{array}{l}\text { Abolition of fees for convales- } \\
\text { cent treatments }\end{array}$ & 50.49 & 82.42 & Yes \\
\hline
\end{tabular}




\begin{tabular}{|c|c|c|c|c|c|}
\hline \multirow[t]{14}{*}{ Slovakia } & $\begin{array}{l}22 \text { Octo- } \\
\text { ber } 1994\end{array}$ & $\begin{array}{c}\text { Retrospective disclosure of } \\
\text { financial transactions regarding } \\
\text { privatizations }\end{array}$ & 19.97 & 93.64 & No \\
\hline & \multirow[t]{4}{*}{$\begin{array}{l}24 \text { May } \\
1997\end{array}$} & Direct presidential elections & $\begin{array}{l}\text { Un- } \\
\text { known }\end{array}$ & & No \\
\hline & & Deployment of nuclear weapons & $\begin{array}{l}\text { Un- } \\
\text { known }\end{array}$ & & No \\
\hline & & NATO membership & 9.51 & & No \\
\hline & & Creating military bases & $\begin{array}{l}\text { Un- } \\
\text { known }\end{array}$ & $\begin{array}{l}\text { Un- } \\
\text { known }\end{array}$ & No \\
\hline & $\begin{array}{l}26 \text { Sep- } \\
\text { tember } \\
1998\end{array}$ & $\begin{array}{l}\text { No privatizations of strategically } \\
\text { important enterprises }\end{array}$ & 44.06 & $\begin{array}{l}\text { Un- } \\
\text { known }\end{array}$ & No \\
\hline & $\begin{array}{l}11 \text { No- } \\
\text { vember } \\
2000\end{array}$ & $\begin{array}{l}\text { Amendments to the Electoral } \\
\text { Law in order to hold early elec- } \\
\text { tions of the National Council }\end{array}$ & 19.98 & 95.07 & No \\
\hline & $\begin{array}{l}3 \text { April } \\
2004\end{array}$ & Early general elections & 35.86 & 87.91 & No \\
\hline & \multirow{6}{*}{$\begin{array}{l}18 \text { Sep- } \\
\text { tember } \\
2010\end{array}$} & $\begin{array}{l}\text { Abolition of concession fees for } \\
\text { broadcasting and television }\end{array}$ & 22.84 & 90.63 & No \\
\hline & & $\begin{array}{l}\text { Limitation of parliamentary im- } \\
\text { munity }\end{array}$ & 22.84 & 98.21 & No \\
\hline & & $\begin{array}{l}\text { Reduction of the number of } \\
\text { parliamentary seats }\end{array}$ & 22.84 & 96.01 & No \\
\hline & & Ceiling price for official vehicles & 22.84 & 93.51 & No \\
\hline & & Elections via Internet & 22.84 & 76.02 & No \\
\hline & & $\begin{array}{l}\text { No right of reply for office hold- } \\
\text { ers }\end{array}$ & 22.84 & 84.79 & No \\
\hline & \multirow[t]{3}{*}{$\begin{array}{l}7 \text { Febru- } \\
\text { ary } 2015\end{array}$} & $\begin{array}{c}\text { Only a bond between one man } \\
\text { and one woman can be called } \\
\text { marriage }\end{array}$ & 21.41 & 94.5 & No \\
\hline & & $\begin{array}{l}\text { Same-sex couples or groups } \\
\text { should not be allowed to adopt } \\
\text { and raise children }\end{array}$ & 21.41 & 92.43 & No \\
\hline & & $\begin{array}{l}\text { Schools cannot require chil- } \\
\text { dren to participate in education } \\
\text { pertaining to sexual behaviour or } \\
\text { euthanasia if the children or their } \\
\text { parents don't agree }\end{array}$ & 21.41 & 90.32 & No \\
\hline $\begin{array}{l}\text { Czech } \\
\text { Republic }\end{array}$ & - & - & - & - & - \\
\hline
\end{tabular}

Source: Centre for Research on Direct Democracy 
This situation clearly shows that Mečiar's political party effectively used democratic procedures to obtain benefits, which discredited democracy. The unsuccessful referendum on the NATO membership resulted in excluding Slovakia from the group of countries invited in 1997 during Madrid summit to join the NATO (Hacker, 2010, p. 167). The unsuccessful referendum on the NATO membership also resulted in negative attitudes of the Hungarians towards using a referendum in important political questions (Bowler, Donovan \& Karp, 2007, p. 352). Among all Slovakian referenda, four of them were initiated by the political parties which lost their support in the parliamentary elections. The goal of these parties was to rebuild their strong position by collecting voices of proponents in various ways, including organizing a referendum (Zieliński, 2003, p. 67). The citizens boycotted the referenda as they were seen only as voting for or against the government, without focusing on solving political and economic problems.

The last Slovakian referendum in 2015 concerned controversial moral issuessame-sex marriages, same-sex adoption, and sex education at school. Prior to the referendum, the Parliament inserted the definition of traditional marriage (a union between a man and a woman) into the Constitution (Art. 41). The amendment of 2014 excludes the possibility of recognizing the relationship between people of the same sex. The 2015 referendum was initiated by the Alliance for the Family and supported by the Conference of Slovak Bishops and Pope Francis. The ruling Social Democrats were criticized for organizing this voting to solve the ethical problem instead of broad discussion in this field. The opponents successfully encouraged the citizens not to vote. The 2015 referendum was unnecessary because the Slovak law does not allow same-sex marriages or civil unions. Secondly, it did not fit the constitutional requirement that a referendum could be held on an important issue of public interest. This voting also had a discriminatory character as the European Court of Human Rights (ECtHR) has clarified that that sexual orientation is one of the prohibited grounds of discrimination listed in Article 14 of the European Convention of Human Rights (ECHR) ${ }^{4}$. However, according to the referendum's initiators, the voting approved the conservative line of Slovak society and defense of traditional family values.

In Hungary, two unsuccessful referenda concerned direct presidential elections (1990) and keeping of hospitals in state ownership and granting preferential Hungarian citizenship (2004). Low turnout in the 1990 referendum resulted from the society's apathy. It was the fourth election organized within eight

$4 \quad$ In the case Schalk and Kopf v. Austria [2010] the ECtHR highlighted that the reference to "men and women" in the ECHR no longer means that "the right to marry enshrined in Article 12 must in all circumstances be limited to marriage between two persons of the opposite sex. 
months; either political parties were not interested in the referendum (Podolak, 2009 , p. 232). All parties apart from the initiator of this referendumHungarian Socialist Party - did a lot to make eligible citizens not participate in the referendum and to make the results non-binding (Podolak, 2010, p. 285). The referendum on direct presidential elections did not gain public support because people preferred the traditional method of presidential election, which is by parliament. At the 1990 referendum the question was explored by the Constitutional Court (CC). In its Judgment No. 1/1990 (II.12) the CC stated the decision taken by the people had only been a referendum in so far as it dealt with the system of presidential election and not in so far as it dealt with the length of the presidential term (Zlinszky \& Sik, 1996, p. 109).

The 2004 referendum on dual citizenship is interesting for some reasons. The opposition Fidesz engaged in the referendum to grant dual citizenship to Hungarians living abroad, though in 2001 Fidesz government adopted a legislation granting the Hungarian diaspora the status of Hungarian ethnic affiliation, along with numerous social benefits (Minkenberg, 2015, p. 39). The novel aspects of the referendum proposal were not to introduce dual citizenship. As Kovács and Tóth said,

the innovation would have been to remove all residency requirements from the pre-conditions for obtaining a Hungarian second citizenship. Ethnic Hungarians in neighbouring states, and possibly living elsewhere, were to be granted opportunity of obtaining thela Hungarian citizenship merely by declaring themselves as of Hungarian linguistic affiliation. (Kovács \& Tóth, 2009, pp. 158-159)

A new era in relations between the Hungarian state and the ethnic-Hungarian diaspora begun in 1988 when one of the Hungarian officials stated: "We consider the Hungarians living beyond our borders as a part of our nation and our policy feels responsibility for their fate" (Butler, 2007, p. 1119). The referendum question on dual citizenship addressed the nature of citizenship and the definition of the nation. Both unsuccessful referenda (1990 and 2004) remained a legitimizing tool for party competition in the field of national politics and resulted in low turnout.

Other Hungarian referenda have been valid; however, the lowest participation was in the voting on NATO membership. The turnout lower than 50 per cent was interpreted as a sign of a high level of indifference to NATO (Black, 2000, p. 73). Hungary was the most vulnerable of the three candidates for NATO accession. The Hungarians have not been strong supporters of NATO as they did 
not understand NATO's obligations and implications of this referendum (Simon, 2003 , p. 48). In turn, the first referendum of 1989 resulted in a clear rejection of the old political system and facilitated real changes in the governmental structures (Suksi, 1993, p. 116). Nevertheless, the first question to determine when the President of Hungary should be elected had a political basis. The postcommunists were interested in presidential elections before the parliamentary ones. This schedule would strengthen their candidate and finally the party's chances for victory in parliamentary elections (Goldman, 1996, p. 192). In the 2008 referendum the citizens were manipulated by the politicians to advance their narrow, selfish interests. Rigging a direct vote in this case involved the phrasing of the question in consideration, which might bias the answers in a hidden manner (Altman, 2014, p. 91).

Referring to Dahl's definition of the "quality" of democracy, a question arisesmust citizens have the right to participate or must they participate? What happens if they do not participate in a referendum? In the case of Slovakia and Hungary a referendum was a farce and distorted the concept of civil society.

\section{Referenda on the EU membership}

As the question of the EU membership is a crucial one from a constitutional standpoint, it seems worth comparing the referenda on the EU accession held in 2003 in all analyzed countries. As de Waele (2005, p. 9) observed, the governments in Central Europe seem to have felt that this "back to Europe" move had to be ratified by "democratic motivation". Political parties and elected representatives often seem too discredited and distant from the cares of the people to take responsibility for such a heavy, thoroughgoing move regarding the future of the country (de Waele, 2005, p. 9). Accession to the EU was regarded as a symbolic connection with the Western democracies and a vital issue for the future of all citizens (Musiał-Karg \& Lesiewicz, 2015, p. 176).

The time of referendum on the EU membership was carefully tailored in accordance with the domino strategy adopted in 1990s, when referenda on the EU membership took place in Austria, Finland, Sweden and Norway (Jahn \& Storsved, 1995, p. 21). The domino strategy was almost successful, except for Norway (Pettersen et al., 1996, p. 265). According to the strategy, the time of a referendum must be coordinated. The sequence of referenda depended on the support declared for 
the EU in particular countries. ${ }^{5}$ It was believed that enthusiasm for European integration, which had already been expressed by successful referenda in some European countries, would be spread among other voters. In 2003, the domino strategy proved to be successful. As Tucker, Pacek and Berinsky (2002, p. 559) rightly predicted, the winners (countries of Eastern and Central Europe) who had done well by the transition were likely to support the EU membership as it ensured a continuation of the transition process from which they have benefited.

\section{Table 4. Referenda on the EU membership in Central Europe}

\begin{tabular}{|l|c|c|c|c|c|}
\hline Date of vote & Country & Turnout, \% & $\begin{array}{c}\text { In favour, } \\
\%\end{array}$ & Against, \% & Result \\
\hline 12 April 2003 & Hungary & 45.59 & 83.76 & 16.24 & Yes \\
\hline $\begin{array}{l}16-17 \text { May } \\
2003\end{array}$ & Slovakia & 52.12 & 93.71 & 6.29 & Yes \\
\hline $\begin{array}{l}13-14 \text { June } \\
2003\end{array}$ & $\begin{array}{c}\text { Czech } \\
\text { Republic }\end{array}$ & 55.18 & 77.33 & 22.67 & Yes \\
\hline
\end{tabular}

\section{Source: Centre for Research on Direct Democracy}

As the authorities of Slovakia and the Czech Republic were afraid of low participation (below 50\%), which might have resulted in the invalidity of the referendum, they organized referenda lasting for two days. This was a correct assumption. A one-day referendum was held in Hungary, as only 25 per cent participation was required for validity. The highest participation was in the Czech Republic (more than 55\%), while the strongest support for the EU was (surprisingly) in Slovakia.

\subsection{Hungary}

European integration has been a priority in Hungarian politics since the early 1990s (Arató, 2005, p. 43). For many years the Hungarians were seen as one of the most the EU enthusiastic nations in Europe. Exit polls showed that at least 70 per cent of participants would vote for the EU (Fölsz \& Tóka, 2006, p. 150). Therefore, the leaders of the Visegrad Group decided that Hungarians would vote first and the great result would be followed by other nations in Central Europe. Results of the EU referendum were supposed to determine where

5 The sequence of holding the referendum was the following: Malta (9 March 2003), Slovenia (23. March 2003), Hungary (12 April 2003), Lithuania (10-11 May 2003), Slovakia (16-17 May 2003), Poland (7-8 June 2003), the Czech Republic (13-14 June 2003), Estonia (14 September 2003), and Latvia (20 September 2003). 
Hungary actually belongs to: is Hungary the Western part of Europe, or, as a country of Soviet occupation, the westernmost part of Eastern Europe. ${ }^{6}$

The relatively low turnout (less than $46 \%$ ) was a big surprise as all political parties supported the EU membership. Indeed, the 45 per cent turnout was equal to the lowest turnout in any valid national vote in post-communist Hungary (the second round of the 1990 parliamentary elections) and the lowest in any EU accession referendum to date (Fowler, 2003).

\section{Table 5. Reasons for not participating in Hungarian referendum on EU membership}

\begin{tabular}{|l|c|}
\hline The main reasons of not voting & $\%$ \\
\hline I was convinced that "yes" results were inevitable & 57 \\
\hline I was too busy to vote & 57 \\
\hline I believed the accession was good but not important enough to vote for it & 51 \\
\hline Due to disunity, mixture of "yes" and "no" arguments by politicians & 34 \\
\hline I believed the accession was bad but I did not want to vote "no" & 27 \\
\hline Due to weather & 11 \\
\hline
\end{tabular}

Source: Fowler, 2003

The reasons for not participating in Hungarian EU membership referendum clearly show that the level of 25 per cent participation required for the referendum's validity could demobilize many Hungarian citizens who had decided - taking into account the various surveys, mood, perception that issues are resolvedthat they do not necessarily have to bother to vote in the referendum.

The "yes" camp consisted of all four parliamentary parties, the governing Socialists and the liberal Alliance of Free Democrats, the opposition right-wing Fidesz and Democratic Forum (Fowler, 2013). Complaints were directed at the government due to both an expensive and ineffective campaign. The Hungarian government was accused of a propaganda campaign instead of showing the conditions and results of the EU membership. The opposition party Fidesz was blamed for a low turnout, too. Fidesz did not want to lose its conservative electorate, did not clearly support the EU accession and eventually promoted the attitude: "Yes, but...". The campaign against the EU membership was conducted by the small far-left Workers' Party and by extreme right - the Party

6 At the beginning of the $20^{\text {th }}$ century, the famous Hungarian poet Endre Ady used the metaphor that Hungary is a "ferry-state", coming and going between two "riverbanks" [Western and Eastern Europe] (cited in Arató, 2005, p. 45). 
of Hungarian Justice and Life, the diasporic World Federation of Hungarians, and a number of smaller groups. Those anti-EU groups organized themselves into Movement for a Free Hungary (Fowler, 2013). None of them has been in the Hungarian parliament. They underlined that they were not against Europe but against the accession terms of the EU. The differences in preference for EU accession in Hungarian counties are not significant (about more or less 7\%). In every county, more than 80 per cent of inhabitants were in favour of the EU accession.

\subsection{Slovakia}

The Slovakians were the most enthusiastic. More than 95 per cent of voters supported the EU membership. However, there had been a lack of debate on the EU during the last ten years before any referendum. The lack of Slovakian debate on the EU is regarded as the "frozen public discourse" inherited from the communist period and from internal Slovak politics (Kusa, 2005, p. 115). Nevertheless, the campaign was influenced by two factors: the broad consensus among political parties that Slovakia needed to join the EU and the urgent need to ensure a sufficient turnout (Henderson, 2003). The lowest support for the EU membership was in Eastern Slovakia-Medzilaborce, which in 2002 recorded the highest communist vote. Eastern Slovakia is a rural area with little employment opportunities, which caused the high communist vote (Henderson, 2003). However, the Communist Party of Slovakia finally supported the accession to the EU and recommended its members and voters to vote for in a referendum (Sawicki, 2013, p. 75). There was a broad political consensus on the EU membership. Accession was approached as a goal without any other alternative (Gyárfášová, 2004, p. 71).

\section{Table 6. Reasons for non-participation in Slovakian accession referendum}

\begin{tabular}{|l|c|}
\hline Reasons for non-participation in the accession referendum & $\%$ \\
\hline I am disgusted by the political situation in Slovakia & 63.7 \\
\hline I do not see the usefulness of the referendum & 13.7 \\
\hline My vote is not significant & 14.3 \\
\hline My relatives and friends will not participate & 6.1 \\
\hline Other reasons & 5.7 \\
\hline I am not interested in the referendum & 12.6 \\
\hline Total & 100 \\
\hline
\end{tabular}

Source: Kusa, 2005, p. 116 
The main reason for not participating in the Slovakian EU membership referendum was dissatisfaction with the domestic political situation and the political disputes. The accession referendum in Slovakia was unable to break the new Slovak tradition of contempt for the plebiscitary form of decision-making. Low turnout resulted from the opportunity to express dissatisfaction with the restrictive social policy of Dzurinda's government (Belko \& Kopeček, 2003, p. 199).

\subsection{The Czech Republic}

Membership of the EU was the key goal for all post-communist governments in the Czech Republic (Lyons, 2007, p. 524). Since the Czech referendum law was limited to one specific case, the deputies did not establish any special conditions for the validity of the result. Politicians agreed in this particular case that they would respect the voice of the people. The referendum was thus acknowledged as binding. The Czech politicians discussed a 50 per cent requirement, but eventually they did not adopt this option. Moreover, the unexpected election of Václav Klaus as the President by the Czech parliament in February 2003, complicated the referendum campaign (Hanley, 2003). Klaus did not clearly support the EU. The politicians feared that the turnout may not be sufficient, since communal and Senate elections have not achieved a participation rate exceeding 30 per cent. Finally, politicians decided to hold a two-day referendum-on Friday and Saturday (Valach, 2004, p. 50).

The official referendum campaign was neither long nor particularly intense (Perottino, 2005, p. 25). The government coalition (Social Democratic Czech Party, Christian-Democratic Union-Czech People Party and Union for FreedomDemocratic Union) supported the EU accession. Two Euroskeptical parties (The Civic Democratic Party and the Communist Party) turned against Brussels' bureaucracy and its temptation of "creeping socialism" (Perottino, 2005, p. 27). The Civic Democrats' referendum campaign concentrated on criticism of political opponents (Hanley, 2004, p. 706). The Communist Party tried to show the negative effects of the EU accession. However, the final choice was left to the voters.

On 13-14 June 2003, for the first time the Czechs participated in the referendum. More than 55 per cent of eligible citizens participated in it; more than 77 per cent voted in favour. This referendum can be regarded as a successful step towards a more democratic society in a country not well experienced in direct participation in public affairs. The strongest support for the EU membership was in Prague, in the districts Praha-zapád, Plzeň-mesto, Brno-město, Brno-venkov, in south- 
eastern Moravia, in Ostrava-město and in the Opava region (ČS $\breve{S}, n . d$.). The lowest support was in Middle Bohemia and the districts bordering Germany, Austria and in four districts bordering Poland (Baun et al., 2006, p. 264). The EU membership obtained equal support for all segments of population: inhabitants of country and towns, seniors and first-time voters, academics and people having basic education. Only voters of the Communist Party largely voted against the EU.

A relatively low turnout can be surprising. The European integration was one of a few areas in which the majority of public opinion coincides with the government's opinion. Public television broadcasted numerous educational programs concerning the EU (Kusa, 2005, p. 121). According to Krenzler and Krok-Paszkowska (2003), low turnout shows low levels of trust in the state institutions, a lack of communication between state and citizens, and a lack of identification with and loyalty to political parties. On the other hand, participation in the accession referendum and elections to the European Parliament brought contradictory results: 55 per cent in the referendum and 28 per cent in the European elections (Krejči, 2005, p. 446).

The relatively low participation in the EU referendum in Hungary, Slovakia and the Czech Republic can be explained by the fact that European integration issue is not exactly independent from domestic politics. This attitude drives the referendum vote in accordance with government's popularity (de Vreese \& Semetko, 2004, p. 18). The low turnout frequently corresponds with the participation in national elections and in the European elections in most EU Member States (Illner et al., 2006, p. 158).

\section{Conclusions}

The aim of this paper was to analyze the political role of referendum in the Czech Republic, Slovakia and Hungary, which was measured by the number of conducted referenda, their validity, people's participation and the results influencing the political and economic system. The first conclusion is that the political role of a referendum is not the same in the analyzed countries. As far as the number of conducted referenda is concerned, the Czech Republic is the least experienced in comparison with Slovakia and Hungary. Since 1989, the Hungarians have voted six times in referendum, the Slovakians eight, while the Czechs did so only once. Why a referendum was more frequently used in Slovakia and Hungary? The referenda frequency and the subject matter 
of the vote mostly depended on the Slovak government. Slovakian referenda had been mainly part of the political struggle between the government and the opposition parties. The Slovak voters rightly did not perceive a referendum as an influential instrument to express their real views, but rather as a convenient tool for the policy-makers in the political struggle. In general, the Slovaks are not convinced that the "man in the street" can change anything in the political sphere. In Slovakia a referendum has a plebiscitary form of decision-making. The opposition political parties repeatedly used it against the government. Only one Slovakian referendum was successful - that on the EU membershipsupported by all political parties, with a few irrelevant exceptions. As far as the Hungarian referenda are concerned, two of them have been unsuccessful (1990 and 2004) as they remained a legitimizing tool for party competition.

There are a few similarities in the analyzed countries with a relatively low turnout. In general, the citizens were reluctant to participate in the referenda. Voters' behaviour in national referenda is comparable to the EU accession referendum. People voting for or against followed the attitudes of political parties. Referenda results legally and constitutionally have provided a sufficient basis for political reforms or the EU membership. But in general, voters do not represent the people as a whole because there is always a possibility that the voters misrepresent the public since non-voters may have different views from the voters.

The aim of this paper was also to verify two hypotheses. The first one of the weak usage of a referendum was not entirely confirmed. In total, 15 referenda were organized in the Czech Republic, Slovakia and Hungary over the past 26 years. This is not a great number, however, it should be stressed that no one in Central Europe expects the increasing number of forms of direct democracy. Central European states did not have either the patterns of a referendum, or previous experiences in it. The Czechs, the Slovaks and the Hungarians believe in representative democracy. The low turnout in the majority of referenda confirmed lack of people's belief in political influence. The voter turnout (effective participation) seems to be an important measure of the "quality" of democratic life. The voters usually underestimate their own influence on the decisions of the public authorities. Thus, a referendum has a marginal role in the politics of Central European states and it is not a panacea for solving problems of these countries. A referendum has been often used by the politicians instrumentally. 
Dr hab. Elżbieta Kużelewska is head of the Centre for Direct Democracy Studies at the Faculty of Law, University of Bialystok, Poland. Her academic work involves problems of direct democracy, citizens' participation in political life and social dimension of European integration. She is the author of two books in Polish: Referendum in the Process of European Integration (Warszawa, 2005) and Ratification of the Treaty establishing Constitution for Europe and its results (Warszawa, 2011). She is co-editor of books published within the European Integration and Democracy Series: The Challenges of Modern Democracy and European integration, ed. by E. Kużelewska \& D. Kloza (Warszawa, 2011), European Elections as a Challenge for Democracy, ed. by E. Kużelewska \& D. Kloza (WarszawaBiałystok, 2012), and European Judicial Systems as a Challenge for Democracy, ed. by E. Kużelewska, D. Kloza, I. Kraśnicka \& F. Strzyczkowski (Cambridge, Antwerp \& Portland, 2015).

\section{References}

Altman, D. (2014), Direct Democracy Worldwide, New York: Cambridge University Press.

Arató, K. (2005), 'EU referendum in Hungary,' in J.-M. de Waele (ed.) European Union Accession Referendums, Brussels: Editions de l'Université de Bruxelles, pp. 43-64.

Baun, M.; Dür, J.; Marek, D. \& Šaradín, P. (2006), 'The Europeanization of Czech Politics: The Political Parties and the EU Referendum,' Journal of Common Market Studies, vol. 44, no. 2, pp. 249-280.

http://dx.doi.org/10.1111/j.1468-5965.2006.00622.x

Belko, M. \& Kopeček, L. (2003), 'Referendum in theory and practice: the history of the Slovak referendums and their consequences,' Central European Political Studies Review, vol. 5, no. 2, pp. 193-201.

Bentham, J. (2001[1891]), A Fragment on Government, Union, NJ: The Lawbook Exchange, Ltd.

Black, J. L. (2000), Russia Faces NATO Expansion: Bearing Gifts or Bearing Arms? Lanham, MD: Rowman \& Littlefield.

Bookman, M. Z. (1994), 'War and Peace: The Divergent Breakups of Yugoslavia and Czechoslovakia,' Journal of Peace Research, vol. 31, no. 2, pp. 175-187. http://dx.doi.org/10.1177/0022343394031002005

Bowler, S.; Donovan, T. \& Karp, J. A. (2007), 'Enraged or engaged? Preferences for direct citizens participation in affluent democracies,' Political Research Quarterly, vol. 60, no. 3, pp. 351-362. http://dx.doi.org/10.1177/1065912907304108

Brodziński, W. (2012), Nowa konstytucja Republiki Wegierskiej (wprowadzenie do dyskusji), Lecture at the conference 'Aktualne problemy reform konstytucyjnych. 
54. Zjazd Katedr Prawa Konstytucyjnego', 12 May. Retrieved from www.54zjazdkatedr.uwb.edu.pl/images/referaty/nowa_konstytucja_republiki_ wegierskiej.pdf [accessed 7 Apr 2015]

Brzesina, P. (2012), 'From apathy to protest: How the EU's legitimacy is fading?' in E. Kużelewska \& D. Kloza (eds.) The Challenges of Modern Democracy and European Integration, European Democracy and Integration Series, WarszawaBiałystok: University of Białystok, pp. 37-62.

Butler, O. (2007), 'Hungary and the European Union: The political implications of societal security promotion,' Europe-Asia Studies, vol. 59, no. 7, pp. 1115-1144. http://dx.doi.org/10.1080/09668130701607102

Constitution of the Czech Republic (1992), Ústavni soud České republiky, No. 1/1993 Coll., 16 December 2011.

Constitution of the Slovak Republic (1992), Ústava Slovenskej republiky, No. 460/1992 Coll., 1 September 1992.

Csnik, L. (2013), 'Tendencies of direct democracy in Hungary - referendums in a new basic law,' Iustum Aequum Salutare, vol. 4, pp. 59-64.

ČSǓ (n.d.), Czech Statistical Office. Retrieved from http://www.volby.cz/pls/ref2003/ re12?xjazyk=EN [accessed 30 May 2015]

Dahl, R. A. (2000), On Democracy, New Haven: Yale University Press.

(1971), Polyarchy: Participation and Opposition, New Haven: Yale University Press.

de Vreese, C. H. \& Semetko, H. A. (2004), Political Campaigning in Referendums: Framing the Referendum Issue, London \& New York, Routledge. http://dx.doi. org/10.4324/9780203335031

de Waele, J.-M. (2005), 'From membership referendums to European elections,' in J.-M. de Waele (ed.) European Union Accession Referendums, Brussels: Editions de l'Université de Bruxelles, pp. 7-22.

Fölsz, A. \& Tóka, G. (2006), 'Determinants of support for EU-membership in Hungary,' in R. Rohrschneider \& S. Whitefield (eds.) Public Opinion, Party Competition, and European Union in Post-Communist Europe, London: Palgrave Macmillan, pp. 145-164.

Fundamental Law of Hungary (2011), Magyarország Alaptörvénye, Government of Hungary, 18 April 2011.

Glajcar, R. (2004), Instytucja Prezydenta w Polsce, Czechach i Słowacji $w$ latach 1989-2000, Toruń: Adam Marszałek.

Goldman, M. F. (1996), Revolution and Change in Central and Eastern Europe: Political, Economic and Social Challenges, New York: M. E. Sharp, Inc.

Gyárfášová, O. (2004), 'Perceptions of European integration in Slovakia,' Etniškumo studijos / Ethnicity studies, pp. 69-81. Retrieved from http://www.ces.lt/wpcontent/uploads/2012/03/EtSt_Gyarfasova_2004.pdf [accessed 2 Apr 2015] 
Hacker, P. (2010), Slovakia on the Road to Independence. An American Diplomat's Eyewitness Account, University Park, PA: The Pennsylvania State University Press.

Hanley, S. (2003), 'Referendum Briefing No. 6. The Czech EU Accession Referendum 13-14 June 2003.' Retrieved from Opposing Europe Research Network, https://www.sussex.ac.uk/webteam/gateway/file.php?name=epern-ref-no-6. pdf\&site $=266$ [accessed 12 Feb 2015]

— (2004), 'A nation of sceptics? The Czech EU Accession Referendum of 13-14 June 2003,' West European Politics, vol. 27, no. 4, pp. 691-715.

http://dx.doi.org/10.1080/0140238042000249867

Haughton, T. (2002), 'Vladimír Mečiar and his role in the 1994-1996 Slovak coalition government,' Europe-Asia Studies, vol. 54, no. 8, pp. 1319-1338. http://dx.doi. org/10.1080/0966813022000025907

(2003), 'Facilitator and impeder: the institutional framework of Slovak politics during the premiership of Vladimír Mečiar,' The Slavonic and East European Review, vol. 81, no. 2, pp. 267-290.

Henderson, K. (2003), 'Referendum Briefing No. 7. The Slovak EU Referendum Accession Referendum 16017 May 2003.' Retrieved from European Parties Election and Referendum Networks, https://www.sussex.ac.uk/webteam/gateway/ file.php?name=epern-ref-no-7.pdf\&site $=266$ [accessed 8 Apr 2015]

Howler, B. (2003), 'Referendum Briefing No. 4. The Hungarian EU Accession Referendum 12 April 2003,' Retrieved from Opposing Europe Research Network, https://www.sussex.ac.uk/webteam/gateway/file.php?name=epern-ref-no-4. pdf\&site=266 [accessed 12 Feb 2015]

Illner, M.; Čermák, D.; Kostelecký, T. \& Stachová, J. (2006), 'EU accession and the public sphere in new member states: the case of the Czech Republic,' in L. Giorgi, I. von Homeyer \& W. Parsons (eds.) Democracy in the European Union. Towards the Emergence of the Public Sphere, London, etc.: Routledge, pp. 157-180.

Jahn, D. \& Storsved, A. S. (1995), 'Legitimacy through referendum? The nearly successful domino-Strategy of the EU-referendums in Austria, Finland, Sweden and Norway,' West European Politics, vol. 18, no. 4, pp. 18-37. http://dx.doi.org/10.1080/01402389508425105

Kovács, M. M. \& Tóth, J. (2009), 'Kin-state responsibility and ethnic citizenship: the Hungarian case,' in R. Bauböck, B. Perchinig \& W. Sievers (eds.) Citizenship Policies in the New Europe, Amsterdam: Amsterdam University Press, pp. 135-159.

Krejči, O. (2005), Geopolitics of the Central European Region: The View from Prague and Bratislava, Bratislava: The Institute of Political Sciences.

Krenzler, H. G. \& Krok-Paszkowska, A. (2003), 'Public attitudes towards the EU in candidate countries,' Policy Paper, vol. 2. Retrieved from http://cadmus.eui. eu/bitstream/handle/1814/24117/Krenzler.pdf?sequence=1 [accessed 4 Jan 2015] 
Kusa, Z. (2005), 'The accession referendum in Slovakia,' in J.-M. de Waele (ed.) European Union Accession Referendums, Brussels: Editions de l'Université de Bruxelles, pp. 113-138.

Kusý, M. (1999), 'Does the rule of law (Rechtsstaat) exist in Slovakia?,' in J. Přribán̆ \& J. Young (eds.) The Rule of Law in Central Europe: The Reconstruction of Legality, Constitutionalism and Civil Society in the Post-Communist Countries, Aldershot: Ashgate Publishing, pp. 101-117.

Kużelewska, E. (2006), Referendum w procesie integracji europejskiej, Warszawa: Oficyna Wydawnicza Aspra.

(2014), 'Referendum in the Czech Republic and Slovakia,'Annales Universitatis Mariae Curie-Skłodowska, Sectio K Politologia, vol. XXI (1), pp. 97-110.

Locke, J. (1689), Two Treatises of Government, London: Awnsham Churchill.

Lucas, J. R. (1976), Democracy and Participation, Harmondsworth: Pelican.

Lyons, P. (2007), “'It's the economy, stupid!' Popular support for EU accession in the Czech Republic," Sociologický časopis / Czech Sociological Review, vol. 43, no. 3, pp. 523-560. Retrieved from http://sreview.soc.cas.cz/uploads/41d08984 3a069931be48b5c846f09e56b4ae4246_511_3-07\%201yons.pdf [accessed 8 Mar 2015]

Minkenberg, M. (2015), Transforming the Transformation? The East European Radical Right in the Political Process, Abingdon: Routledge.

Musial-Karg, M. \& Lesiewicz, E. (2015), "Direct democracy in the Visegrad Group countries in the context of the Central and Eastern Europe's experiences and membership of the EU - selected issues," in A. Piekutowska \& I. Wrońska (eds.), Ten Years of the Visegrad Group Member States in the European Union, Warszawa: IVF, pp. 169-184.

Perottino, M. (2005), "The Czech accession referendum: 'yes', but no passion," in J.-M. de Waele (ed.) European Union Accession Referendums. Brussels: Editions de l'Université de Bruxelles, pp. 23-30.

Pettersen, P. A.; Jenssen, A. T. \& Listhaug, O. (1996), 'The 1994 referendum in Norway: continuity and change,' Scandinavian Political Studies, vol. 19, no. 3, pp. 257-280. http://dx.doi.org/10.1111/j.1467-9477.1996.tb00393.x

Podolak, M. (2008), 'Referenda na Słowacji,' in S. B. Krajewski (ed.) Polska, Europa, Świat, Lublin: Wyd. UMCS, pp. 223-241.

(2009), 'Referenda w Europie Środkowej i Wschodniej,' in M. Barański (ed.) Modernizacja polityczna $w$ teorii $i$ praktyce. Doświadczenia państw postsocjalistycznych $i$ Trzeciego Świata, Katowice: Śląsk Wydawnictwo, pp. 213-234.

— (2010), 'Referenda na Węgrzech. Teoria i praktyka polityczna,' in H. Chałupczak, M. Pietraś \& P. Tosiek (eds.) Europa Środkowo-Wschodnia w procesie transformacji i integracji. Wymiar polityczny, Zamość, pp. 275-290. 
(2014), Instytucja referendum $w$ wybranych państwach Europy Środkowej $i$ Wschodniej (1989-2012), Lublin: Wyd. UMCS.

Pridham, G. (2002), “The European Union's democratic conditionality and domestic politics in Slovakia: the Mečiar and Dzurinda governments compared," Europe-Asia Studies, vol. 54, no. 2, pp. 203-227. http://dx.doi.org/10.1080/09668130120116583

Reti, P. (2004), 'Hungary,' in B. Kaufmann \& M. D. Waters (eds.) Direct Democracy in Europe. A Comprehensive Reference Guide to the Initiative and Referendum Process in Europe, Durham: Carolina Academic Press, pp. 67-70.

Rousseau, J. J. (2003[1762]), On the Social Contract, Book II, New York: Dover Publications.

Rytel-Warzocha, A. (2011), Referendum ogólnokrajowe w państwach Europy Środkowo-Wschodniej, Warszawa: Wydaw. Sejmowe.

Rytkó, E. (2008), 'National referenda in Hungary,' Lecture at the $17^{\text {th }}$ Annual Conference of the ACEEEO (Association of European Election Officials), 13 September. Retrieved from aceproject.org/regions-en/countries-and-territories/HU/reports/ hungary-report-on-the-national-referendum-2008 [accessed 7 Mar 2015]

Sawicki, A. (2013), "Referendum Campaign on Slovak Republic's Accession to the European Union," Politické vedy/ Political Sciences, vol. 16, no. 4, pp. 65-84. Retrieved from http://www.politickevedy.fpvmv.umb.sk/userfiles/file/4_2013/ SAWICKI.pdf [accessed 27 Apr 2015]

Schalk and Kopf v. Austria [2010], Application no. 30141/04, Judgment of 24.06.2010.

Schumpeter, J. (1950), Capitalism, Socialism and Democracy, $3^{\text {rd }}$ edition, New York: Harper and Row.

Simon, J. (2003), Hungary and NATO: Problems in civil-military relations, Lanham, MD: Rowman \& Littlefield Publishers.

Skotnicki, K. (2000), System konstytucyjny Czech, Warszawa: Wydaw. Sejmowe.

Suksi, M. (1993), Bringing in the People: A Comparison of the Constitutional Forms and Practices of the Referendum, Dordrecht: Martinus Nijhoff Publishers.

Tucker, J. A.; Pacek, A. C. \& Berinsky, A. J. (2002), 'Transitional winners and losers: attitudes towards EU membership in post-communist countries,' American Journal of Political Science, vol. 46, no. 3, pp. 557-571. http://dx.doi.org/10.2307/3088399

Valach, M. (2004), 'Czech Republic,' in B. Kaufmann \& M. D. Waters (eds.) Direct Democracy in Europe. A Comprehensive Reference Guide to the Initiative and Referendum Process in Europe, Durham: Carolina Academic Press, pp. 48-51.

Zieliński, E. (2003), 'Referendum w Czechach, Słowacji, Słowenii i na Węgrzech,' in E. Zieliński, I. Bokszczanin \& J. Zieliński (eds.) Referendum w państwach Europy, Warszawa: Oficyna Wydawnicza Aspra, pp. 55-80.

Zlinszky, J. \& Sik, M. (1996), 'Constitutional justice and democracy by referendum in Hungary,' in Constitutional Justice and Democracy by Referendum: Proceedings of the UniDem Seminar Organized in Strasbourg, on 23-24 June 1995 in co- 
operation with the "Institut Des Hautes Études Européennes" of Strasbourg, Robert Schuman University, and with the Support of the European Union, Council of Europe. 